\title{
In the Shadow of the City: Demographic Processes and Emerging Conflicts in the Rural-urban Fringe of the Hungarian Agglomerations
}

\author{
Gábor Vasárus ${ }^{A *}$, Péter Bajmócy ${ }^{A}$, József Lennert ${ }^{\mathrm{B}}$ \\ Received: November 03, 2017 | Revised: December 31, 2017 | Accepted: January 9, 2018
}

DOI: $10.5937 / 22-16572$

\begin{abstract}
Because of the special settlement system in Hungary a municipality can be divided into three parts, the central inner area (core city), other inner areas (incorporated settlements) and outskirts. Because of this system and special settlement network, the process of suburbanisation in Hungary has some unique characteristics. In this paper we examined the spatial structure and social properties of the rural-urban fringe of four Hungarian cities, with emphasise on the other inner areas and the outskirts.

The outskirts are mostly scattered or interim habitations within the administrative limits of a city or village but these are usually separated from the main built-up areas and almost all of them characterised remote-rural-like infrastructure and way of life. This spatial structure resulted in the phenomenon of the suburbanisation within city limits. Our research aims to examine how it influenced local society and land use pattern in the rural parts of the agglomerations. The used method was based on a questionnaire involving 1800 households and census of outskirts plots in the sample area of a middle-sized city in West Hungary.

During this process, residents tend to change their living conditions to a more rural one without leaving the municipality, thus areas of former villages and outskirts attracted $55.1 \%$ of suburban movement outside of Budapest Agglomeration since 1990. Most of the residents came from the city to rural milieu and their main motivations were low utility costs, gardening opportunities and slow lifestyle. A significant part of them is especially looking for remote-rural-like environment and community, however they want to stay close to the city. A high proportion of migrants have low-income and disadvantages. The repeated expansion of modest houses resulted in a chaotic townscape that is creating conflicts within neighbourhoods. Even villages, incorporated villages and outskirts, which are at the same distance from the city centre, show significant differences in rurality, suburban motivations and society. The rural-urban fringe transformed into a highly complex spatial and social structure during post-socialist transformation, therefore the existing urban and spatial development methods of Hungarian Administration are not able to handle this phenomenon.
\end{abstract}

Keywords: conflicts, post-socialist urbanisation, inhabited outskirts, segregation

A Department of Economic and Social Geography, Faculty of Science and Informatics, University of Szeged, H-6722 Szeged, Egyetem Street. 2. Hungary; vasarus.geo@gmail.com

B MTA, KRTK, RegionálisKutatásokIntézete, H-6000 Kecskemét, Rákóczi Street. 3. Hungary

* Corresponding author: Gábor Vasárus, e-mail: vasarus.geo@gmail.com 
Over the last two decades, the number of publications concerning suburbanisation processes of the Asian (Yue et. al., 2013) and former socialist countries has significantly increased (Kubes, 2013). It is commonly agreed upon that the classic model of suburbanisation - developed to fit western and Anglo-Saxon countries - does not describe perfectly the ongoing processes of the second and the third world (Ouředníček, 2007; Sýkora \& Bouzarovski, 2011). The differences not only appear in the degree (Timár, 2010), duration (Tammaru, 2001) and spatial characteristics of suburbanisation (Kok, 2000), but specific social relations (Kok \& Kovács, 1999) and settlement geographical conditions (Nuissl \& Rink, 2005) can also generate significantly different subprocesses (Brown \& Schafft, 2002) and a highly fragmented spatial structure (Antrop, 2004).

In Hungary, similarly to other post-communist countries, suburbanisation significantly contributes (Szelényi, 1996) to the changes in the settlement system (Bajmócy, 2003), the land use system and internal migration patterns (Dövényi, 2009). Domestic and international comparative researches (Brown et. al., 2002; Hardi, 2002) revealed many positive (Kok, 2000) as well as negative impacts (Szirmai, 2011; Timár, 1999) on the local communities involved in the process (Brade et. al., 2009; Váradi, 1999). This phenomenon can reshape traditional systems, relationships, interests and identifications within the local society and may lead to serious conflicts (Csanádi et. al., 2002; Kok et. al., 1999).

Urban land use, lifestyle features and functions penetrate rural space, modify the local way of life, furthermore this process significantly transforms the social, environmental and economic characteristics of affected communities (Csatári et. al., 2013). These changes are mostly apparent in the transitional area around the core city in the agglomeration called the rural-urban fridge (Pócsi, 2011). Here, the rapid and extensive transformations resulted an especially fragmented spatial structure characterised by collisions between different interests are unavoidable (Timár \& Váradi, 2001). Therefore, the transforming rural-urban fringes can be seen as conflict zones (Timár, 1993; Timár \& Baukó, 1999).

The years after 1989 saw a rapid expansion of suburbanisation in parallel with population decline and economic recession (Szirmai, 2011). In the light of this phenomenon, researchers in Hungary have identi- fied some unique key features of the process (Brade et. al., 2009). They emphasized the importance of forced outmigration of the underclass into the suburbs because of high utility costs (Csurgó, 2013), and the significant share of rural migrants who looked for a job, but could not afford any housing within the core city, therefore they settled in the urban-rural fringe instead (Dövényi \& Kovács, 1999). Furthermore, the land use of the suburbs is also characterised by second homes, pensioners' holiday cottages and garden zones, which were the recreational substitutes of suburbanisation during the late socialist era (Timár, 1990). Less attractive suburban settlements became migration targets for the broken families (Szelényi, 1996) and the poor, unqualified workforce from remote rural Hungary (Váradi, 1999). This process has been undergone in parallel with the commencing reurbanisation, revival of downtowns and job centralization (Bajmócy \& Makra, 2016).

Another unique trait of suburbanisation in Hungary that a significant share of people moving from urban to more rural neighbourhoods does not leave the administrative borders of the core city (Hardi, 2002). Their migration targets include former villages previously attached to the cities and inhabited scattered settlements at the outskirts of the city (Bajmócy, 2000). A particularly high proportion of former countryside dwellers are involved in this process (Balogh \& Csapó, 2013), because they usually want to return to their rural lifestyle (Szirmai, 2011). These formerly incorporated villages and inhabited outskirts can also be considered as part of the rural-urban fringe and can be identified as conflict zones (Pócsi, 2009; Pryor, 1968).

While suburbanisation received special attention in the literature of post-communist settlement geography, some of its subprocesses have avoided largescale scientific interest (Hardi, 2012; Kovács, 1999). This is especially true for the transformation and emerging problems of other inner areas and outskirts within the administrative borders of the city, which areas have drawn only limited attention so far compared to the suburbanisation of sovereign settlements (Balogh, 2012a). In order to address this neglected issue, our present analysis focuses on the demographic processes, the changes in the local society and new problems and conflicts of these areas in four case study cities. 


\section{The overlooked elements of the settlement structure: the typology and characteristics of the outskirts and other inner areas}

In our research we used the following definition of suburbanisation: the process of decentralization of urban population and activities, in the sense of a part of the population, the productive and non-productive activities, the capital and the investments concentrate into the settlements around the cities instead of the urban centres, regardless of administrative borders (Bajmócy, 2014; Ouředníček, 2007; Timár, 1999).

This definition implies that the interpretation of settlements can deeply influence the perception of suburbanisation. For example, the settlement system of Hungary, as it can be defined in the terminology of human geography, does not completely match the system of local administrative units. Besides the officially delineated, densely built-up central inner area (the historical core and its expansions), we can often find other inhabited "settlements" within the administrative border of the city: officially distinguished other inner areas and different type of inhabited outskirts (Bajmócy, 2014). The other inner areas are mostly former villages which had been incorporated into the administrative area of the larger settlements but did not merged into it in the physical sense (Ónodi et. al., 2002). Due to the unique development of the Hun- garian settlement system, we can also indentify different types of inhabited outskirts (like tanyas, wine hills, garden zones, manors, industrial or Roma settlements) which can provide home for a significant number of dwellers (Pócsi, 2011) (Figure 1).

In Hungary, settlement merging has a long tradition. The involved village or small town will disappear in the sense of statistical and legal terms, but they do not lose their rural character or society for a long time (Bajmócy, 2003). During the socialist era incorporating was one of the main tools of forced urbanisation and rural industrialisation. A significant share of these cases could not be explained with social or settlement geographical reasons and usually the physical distance between central and other inner parts has not disappeared, and these formerly sovereign settlements managed to preserve their identity. The major part (94\%) of the population lives in the central inner parts of the settlements, but 3\% live at the other inner parts and $3 \%$ at the outskirts (Bajmócy \& Makra, 2016). In addition to the statistically-existent villages there are a large number of ones attached to cities; most of them are within the area of settlements of agglomerations (Timár, 1993). While very often there is

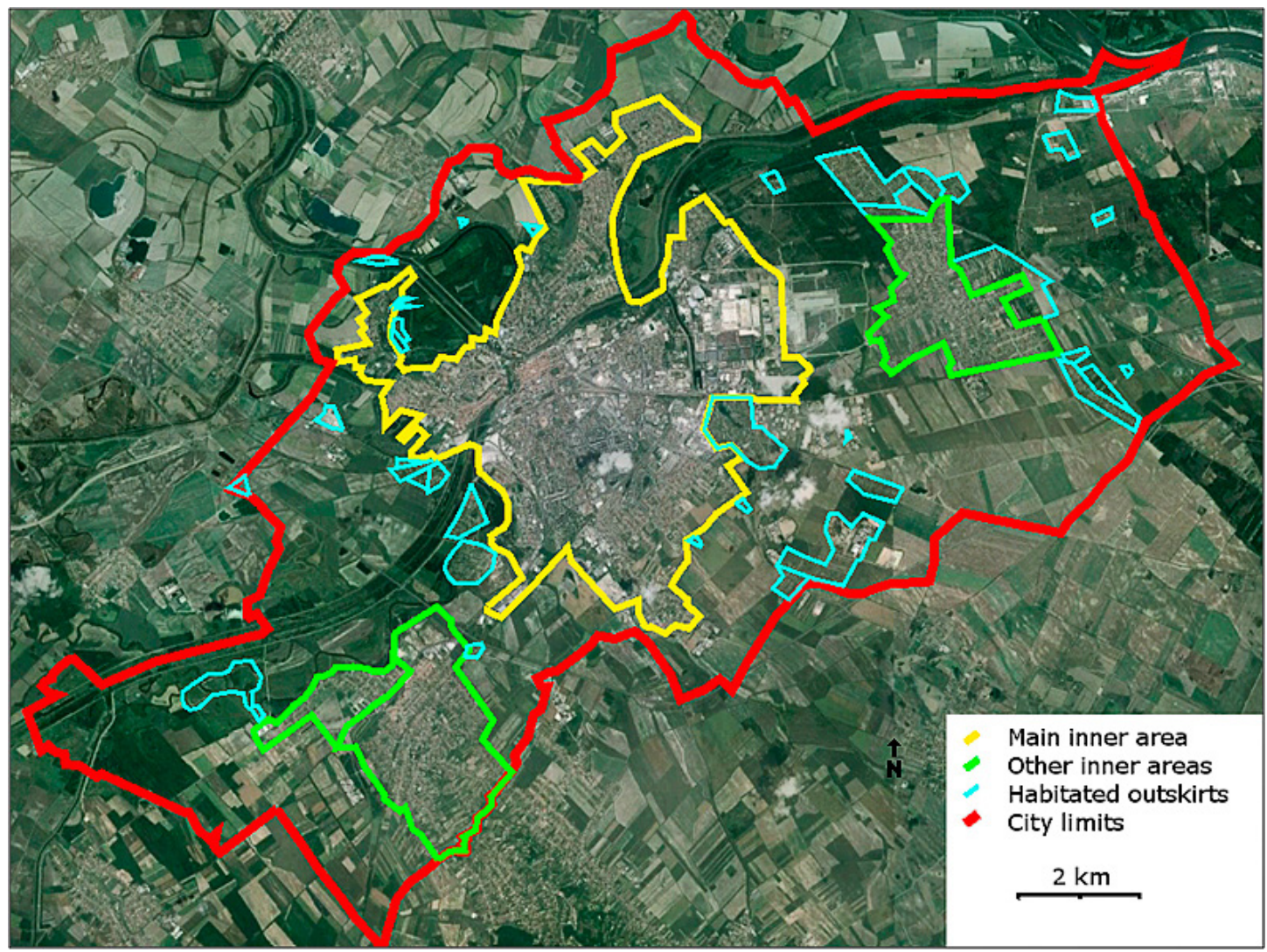

Figure 1. Spatial and administrative structure of a Hungarian city

Source: Edited by the authors, background: google.maps.com 
no difference between the processes and characteristics of the other inner areas and the neighbouring administratively independent villages, most of the statistical data collection and analysis focuses on local administrative units only. As a result, a large part of the transformation of the rural-urban fringe remains unseen (Balogh, 2012a).

The geographical, historical and social characteristics of the country brought a range of special inhabited outskirts into existence. The individualism, the mosaic spatial structure and the emergence of internal frontiers after the decay of the medieval village system all contributed to the formation of these scattered settlement types (Csapó \& Balogh, 2013).

The "tanya" is the most distinctive form of outskirts. It is a scattered farm-like habitat, which was emerged in the Great Hungarian Plain after the Ottoman rule (Balogh \& Csapó, 2013). The birth of the tanya is connected to the shift from semi-nomadic cattle-breeding to farming activity. Because the Ottoman rule left a very sparse settlement network, it was necessary to establish a system of scattered settlements in order to cultivate the inner frontiers of the Great Hungarian Plain. Though it is a scattered settlement, it was formed as an integral part of the city, because its inhabitants were traditionally urban citizens with a house in the inner area (Becsei, 2010). They spent their summers on the tanya with agricultural activity, while they lived in their home in the city during the winters and their old age. This double residential pattern is the main characteristic of the tanya system. Many researchers see it as a revival of nomadic dual (winter and summer) habitation system, while other scientists consider it as a specific urban area form, produced by the unique social and economic processes in the era (Becsei, 2015).

The number of inhabitants living in the tanya reached its peak in the first half of the 2oth century. In the socialist era, in order to push forward collectivization, the government systematically neglected the farms, thus only a third of the tanyas persisted till 1990, and even those were in poor condition (Csatári \& Farkas, 2012). After the transition, the remaining tanyas underwent significant differentiation based on their agricultural and social processes. Some of them continued to decline, while the easily accessible ones became the targets of suburbanisation and de-urbanization (Kovács, 2010).

The other parts of the country are dominated by manors and wine hills. The manor is a hamlet-like small-scale settlement (Figure 2.) without administrative sovereignty which was originally established around a landlord's property (Balogh, 2012a). The estate consisted of a castle or mansion, some poorly constructed rowhouses for the workers and numerous large agricultural structures, but most of them are now in ruined condition. Typical population size ranged between 10 to 100 residents, and in most cases only agricultural and residential functions appeared in these settlements (Pócsi, 2011). They are characterized by small enclosed communities and administrative subordination to the core settlement.

The wineyards form a system similar to tanyas, but the houses much more densely located along ridges due to the characteristics of the grape cultivation. Buildings typically form a street-like line, but similarly to the manors, this is a transition type between scattered and nucleated settlements, with no enclosed settlement core (Égető, 2003). They have strong ties to the city, since most of the residents and owners are citizens of the nearby town (Balogh, 2012a).

Garden zones are traditional appendixes of the core inner area since centuries in Hungary. Unlike other outskirts, they are not separated from the inner areas by physical distance but by function and morphological characteristics. While originally built for smallscale agricultural purposes, during the development of the Hungarian towns of the past 100 years, these zones also provided habitat for the underclass, people dislocated from the city, and the unemployed ones migrat-

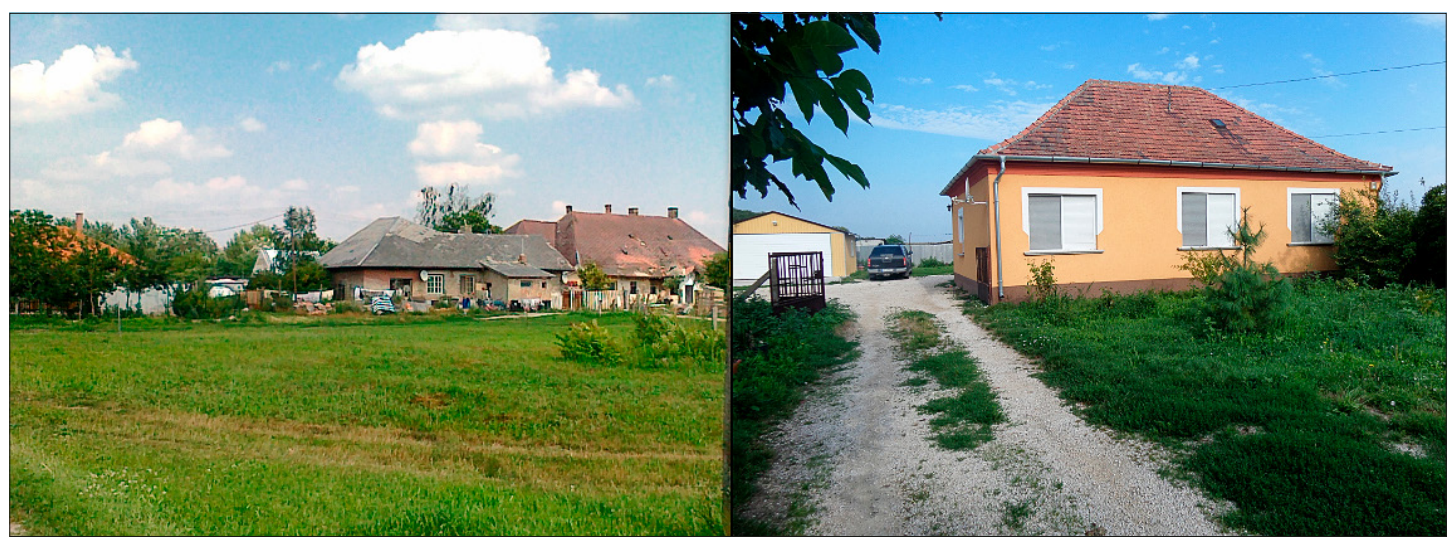

Figure 2. A typical manor and a tanya

Source: own photo 
ing toward the centres from peripheries. Due to cheap plots, additional income from garden work and loose building regulations, they were especially attractive for the least well off people. From the early socialist era, with the establishment of the gardening movement, garden zones became one of the main places for recreation and horticulture as a secondary income source. The small plots in garden zones formed a grid-like settlement pattern with unusually narrow roads and incomplete infrastructure. Parallel with the slow development of infrastructure, the owners started to move to their weekend houses. Most of them used these buildings as secondary homes, but the number of those who permanently settled in the garden zones has been already started to grow in the late socialist era, as a substitute process of suburbanisation.

By the mid-2oth century, some other types of outskirts have been formed, like miners' and industri- al housing estates at outskirts as well as Roma's settlements gained ground. Most of them are similar to hamlets; their main role was to provide housing for the workforce of agricultural, mining or industrial projects in the outskirts, while the Roma groups' housing was based on strong segregation. A significant number of them lacked proper sanitation, safe water supply or other basic human necessities. The composition of properties in these outskirts varield from favela-like huts („putri”) to small block of flats.

The role of rural habitats within the administrative limits of Hungarian cities was important during the post-socialist developmentbecause of the variety of roles described above (Beluszky, 1982). These rural inclusions embedded into urban space and often appear as target areas during the suburbanisation process which further strengthened the local characteristics (Ott, 2001; Csatári et. al., 2013).

\section{Methods and data}

This research is based on a statistical analysis that used conventional social geographical methodology on the data from the general population censuses and additional HCSO (Hungarian Central Statistical Office) data. Based on the examination of population data and internal migration we selected four Hungarian cities as our case studies (Figure 3). Győr and Szeged are regional centres with a large number of outskirts and with some incorporated settlements, thus a signif- icant part of suburbanisation remains within city limits. Hódmezővásárhely and Zalaegerszeg are cities with county rights, they have many outskirts with significant population, and suburbanisation has remained almost entirely within the administrative borders. The selection of these four municipalities is also justified by some geographical features. The "tanya" type outskirts are common in Szeged and Hódmezővásárhely, the manors and wine hills are well preserved in Zal-

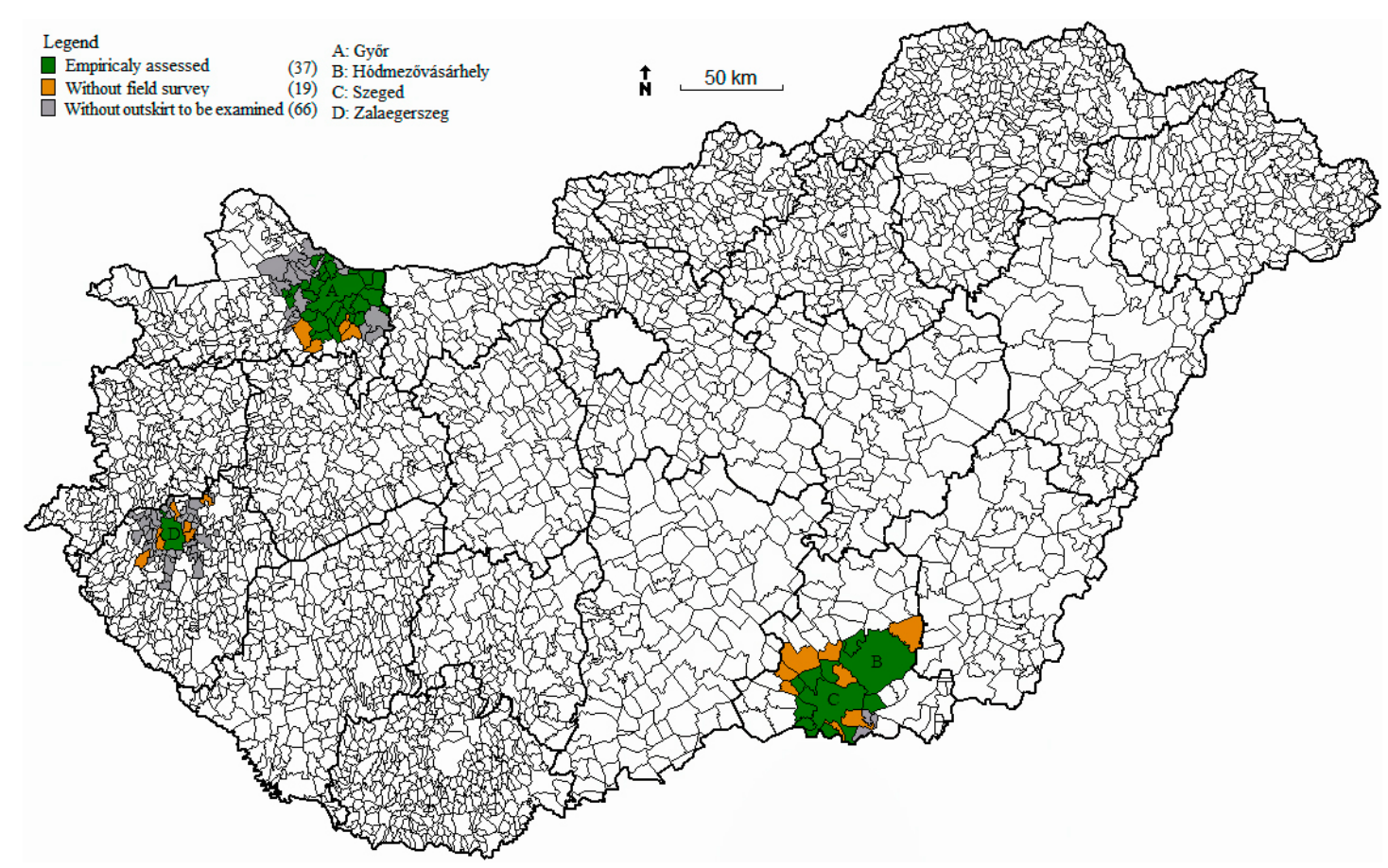

Figure 3. Map of the sample areas

Source: edited by the authors 
aegerszeg and Györ, which are typical features of the Transdanubian region. Moreover two of the four cities are smaller and two have larger population thus our results can be more generally valid for the city stock of the country. The sample areas include all other inner areas and outskirts of the selected four case studies.

The detailed analysis of the sample areas consisted of three steps: survey, field examination and interviews. First we conducted a stratified systematic survey that involved 1200 households in the outskirts and another 600 in the other inner areas of the four towns. With this method, every fifth household of the sample areas was included in the survey. The first third of the questionnaires were asked data about housing and migration-related questions. It followed by questions about the various difficulties and social characteristics of the living space. In the last part we requested details about the demographic characteristic of the household. The participants also had the opportunity to formulate their own problems and expectations in the open-ended questions.
Additional information for the surveys was provided by the accompanying fieldwork, during which we classified the household plots, the state of infrastructure and accessibility of the outskirts. Finally we prepared some interviews with local government leaders and other professionals in the sample area in order to examine their attitude toward development planning, supply tasks and daily routine in connection with outskirts and other inner areas.

The results were quantified by grouping the answerswith emphasis on preserving subjective opinions. We have analyzed the frequency and the correlations of the answers using basic statistical techniques and simple $\mathrm{r} 2$ method. With the combination of these methods, we could get a detailed picture of the demographic processes, social structure, problems and conflicts of the sample areas and these case studies can contribute to the wider understanding of the transformation processes of the rural-urban fringes of Hungary.

\section{Demographic processes and changes in the local society of the outskirts and other inner areas}

From 1990 to 2010, $33.6 \%$ of suburban growth took place in the outskirts and other inner areas (Table 1). This is especially true for agglomerating cities besides Budapest (like our four case studies), where the thin majority of suburban migrants moved to these areas. Villages and the outskirts merged into cities can attract urban out-migrants, because they are mostly interested in the landscape, the condition of infrastructure and the reputation of the place, not in the administrative status of the location.

As a result, the demographic development of these areas after the transition is markedly different from the previous decades. The communist period brought a sharp decline in the population of the outskirts: they lost more than $70 \%$ of their inhabitants between 1960 and 1990. After 1990 the population decline of the outskirts stopped, and we can even see a moderate increase in their population, while the population of the other inner parts started to increase rapidly after 1990, first of all because of the suburbanisation. The demographic processes and following differentiation of the outskirts were in fact similar to the post-socialist development of the small villages (Balogh, 2012b).

According to our empirical research, our sample areas fit into these trends. The main features of the ongoing process can be summarized with the following: half of the outskirts increased their population since the political transition, and all the other inner areas were migration targets during the period. Between 2001 and 2014, the population of the outskirts increased by $92.8 \%$ and the other inner areas also experienced a $21.4 \%$ rise in the number of inhabitants. Garden zones, wine hills and social facilities have attracted the most newcomers (Table 2).

In Hungary, the population of the other inner areas has begun to grow after 1980. The migration from city to second homes and to former villages and move from peripheries of the country to these affordable

Table 1. The role of outskirts and other inner areas as suburban destinations in Hungary.

Share of population growth between parts of settlements

\begin{tabular}{|l|c|c|c|c|c|c|}
\hline & Population & \multicolumn{2}{|c|}{ Cities (\%) } & \multicolumn{3}{|c|}{ Other settlements (\%) } \\
\cline { 4 - 7 } & $\begin{array}{c}\text { growth } \\
1990-2011\end{array}$ & $\begin{array}{c}\text { Other } \\
\text { inner areas }\end{array}$ & Outskirts & $\begin{array}{c}\text { Central } \\
\text { inner areas }\end{array}$ & $\begin{array}{c}\text { Other } \\
\text { inner areas }\end{array}$ & Outskirts \\
\hline Suburbs in Hungary & 484745 & 9.2 & 9.0 & 66.4 & 8.5 & 6.9 \\
\hline Suburbs around Budapest & 296412 & 0.3 & 1.3 & 80.1 & 12.0 & 6.2 \\
\hline Suburbs around other cities & 188333 & 23.1 & 21.0 & 44.9 & 3.0 & 8.0 \\
\hline
\end{tabular}

Source: Own elaboration based on census data (HCSO) 
locations were main drivers of this process (Timár, 1993). This trend continued in the 1990 os and in some areas, even accelerated after the millennium (Bajmócy, 2003). Due to the previously described demographic differences, the integration of newcomers into the local community is laden with conflicts and may take 5-6 years (Hardi \& Nárai, 2005). Due to their urban roots, higher earnings and their way of life, newcomers significantly differ from local-born people (Csurgó, 2013). Immigrants have strong lobbying ability (Weaver \& Lawton, 2001) and a different vision of the future (Schuchmann, 2013). Residential function and quality of services are more important in their vision (Sharp \& Clark, 2008) than the local landscape (Gant et. al., 2010), architectural (Antop, 2004) and cultural heritage (Pacione, 2013). If the newcomers move to newly built streets or gated communities whitin rural-urban fringe, spatial separation also appears (Clouth, 1976) which further hinders the integration (Bryant, 1995; Timár \& Váradi, 2001).

The society of the examined outskirts has significantly revamped by the persistently high number of immigrants. The majority of respondents came from the core city, but also a high proportion of people moved there from the peripheries of the country. Nearly half of the respondents only moved here after the millennium; this is in accordance with the general trend in Hungary that suburbanisation ran up only after 2000.

This is especially true to the upper and middle class, which only began to outflow into the outskirt areas after the acceleration of suburbanisation. The relatively good environment, the looser regulations and the large and relatively cheap properties were attractive for this group (Kovács, 1999). The increasing number of wealthy households started a rural gentrification process in the outskirts (Timár et. al., 200o). The early settlers improve the reputation of the area; this attracts new residents, which raises real estate prices (Bourne, 1996). Through lobbying, the newcomers start to reshape the place of residence to fit into their rural image concept (Csurgó, 2013). They do not perceive the outskirt as a place for agricultural activity with unavoidable inconveniences (smell, noises), they only long for the scenery of an idealized image of rural landscape (Phillips, 2009). This "landscape-fetishism" may contribute to the elimination of traditional land use (Stockdale, 2010) and it leads to the displacement of the original inhabitants (Szirmai, 2011).

We asked the respondents to evaluate the composition of the local community in order to sharpen the image of the transformation of the population. According to the answers from the other inner areas, the substantial majority of the local residents are either high-income migrants from the core area of the city or local born people with average social status. It shows a stark contrast with the answers from the outskirts, where most of the respondents mentioned those who were forced out from the city, career starters, underclass and other disadvantaged groups (Table 3).

However, according to interviewees in the outskirts, nearly $90 \%$ of the newcomers are form the lower third of middle class and are exposed to the risk of impoverishment. They are fleeing to the outskirts because there they are at least able to maintain the semblance of their previous status due to the reduced living costs. However, we can also find immigrants from the upper class concentrated in the best areas of the outskirts.

Their answers also revealed the presence of some groups which do not appear in the official statistics. For example, $13.1 \%$ of the population of outskirts are hobby garden cultivators or ones who lives partly at core city, but they live at the outskirts during the summer half of the year. They do not appear in the statistics as local residents, even if they spend a part of or

Table 2. Population growth of outskirts in agglomerations of Hungary

\begin{tabular}{|l|c|c|c|c|}
\hline \multirow{2}{*}{ Type } & Number of outskirts with & Population change & \multicolumn{2}{|c|}{ Population } \\
\cline { 4 - 5 } & growing population & $1990-2011$ & 1990 & 2011 \\
\hline Social institutes & 12 & 1521 & 1113 & 2634 \\
\hline Manors & 188 & -980 & 5960 & 4980 \\
\hline Inspector homes & 179 & 103 & 2798 & 2901 \\
\hline Peri-urban streets & 144 & 7319 & 6897 & 14216 \\
\hline Wine hills & 252 & 6376 & 3675 & 10051 \\
\hline Garden zones & 76 & 13749 & 5884 & 19633 \\
\hline Holiday cottage zones & 33 & 749 & 136 & 885 \\
\hline Tanyas & 406 & 6267 & 43661 & 49928 \\
\hline Others, mixed & 8 & 629 & 2027 & 2656 \\
\hline All outskirts & 1298 & 35733 & 72151 & 107884 \\
\hline
\end{tabular}

Source: Own elaboration based on census data (HCSO) 
the whole year in the outskirts and they use the local infrastructure. A significant number of them unlawfully live in their properties, which were not built for residential purposes or were made without a construction permit. In addition, similarly to other postcommunist states, a quite high number of residents of the outskirts do not have home address there, most of them still officially hold the address of their previous apartment (Ouředníček, 2007).

Moreover, $11.8 \%$ of the respondents mentioned the problem of the illegal occupiers. Poor, unemployed people from the peripheries of the country tend to permanently or temporarily move into the unused houses, summer houses or roughly built huts. Unfortunately, these buildings are often completely inadequate for habitation because these constructions do not have running water neither heating. Data about the real size of this group is not available, but according to the interviewees' answers, their percentage is steadily increasing due to the high number of extremely poor immigrants.

The different types of outskirts and other inner areas attract and provide home to different socioeconomic groups. New residents in the outskirts can be divided based on their income. For low-paid households, the main preferences were low utility cost, relatively attractive environment, and additional income from horticulture, while middle class households also take the larger plots, rural lifestyle and recreational possibilities into account. This is observable in the case of the study areas too: the population of the examined outskirts and other inner areas have different characteristics. In the case of the other inner areas, nearly two-thirds of the newcomers previously lived in detached houses, and the intention to maintain their lifestyle was an important motivation in their choice of place. From other reasons, familial changes (37.3\%) and proximity of workplace $(30.6 \%)$ were mentioned the most frequently.

The outskirts with the worst accessibility and environmental endowments attract gypsies, migrant workers, divorced people and single-parent families due to the low utility costs (Váradi, 2013). This is not a new phenomenon: after the elimination of Roma settlements in the socialist era, the families usually displaced to the worst quality outskirts (Balogh \& Bajmócy, 2011). After the fall of the socialist regime, the forced migration of poor families from cities to these outskirts accelerated (Balogh \& Csapó, 2013). It is also a general experience in the post-communist cities that the real estate price boom of the inner suburban belt (Schafft, 200o), the increasing unemployment and rising utility costs forced out the low income (McManus \& Ethington, 2007) migrants to the affordable plots of the areas with poor accessibility (Helling, 2002; Kok, 1999).
Sometimes even good accessibility can facilitate segregation and increase the share of deprived groups. Because of their good accessibility and attractive reserve areas, some of the manors, the industrial housing estates and garden zones are attractive for industrial suburbanisation. The capital intensive investments of the corporations as well as large landowners displace local residents from the property market. The increased noise and environmental pollution induced a selective emigration from these areas (Abda - Pillingérpuszta, Győr - Somosmajor, Sashegypuszta). In such outskirt areas - for example Somosmajor - only the elderly and the Romani people remain. They are unable to move out because the lasting environmental inequality made their houses unsellable.

Seemingly paradoxical that intensifying farming activity can also induce similar processes as industrial expansion. While agriculture is a crucial element of the traditional landscape of the outskirts, large-scale agricultural production can also contribute to the irreversible loss of "genius loci". In order to gain more land for crop production, the desolated tanyas are often demolished and then ploughed up. Residents tend to give up their gardens and secondary homes because scenic degradation, dust, allergenic weeds and pesticides have substantial adverse effects on their quality of life. The remaining plots and buildings of the former wine hills, garden zones and manors form islands in the arable land (Pér - Sótóidülő, Győrújfalu - Mártonháza). For example only a single mother and her two children remained in Pázmándfalu - Bercel, because they don't have any financial opportunity to move away.

On the other hand, bad accessibility does not always deter higher status migrants. With their preserved environment, even the remotest outskirts can be attractive for lifestyle changer seniors and artists. The upper and middle class also began to outflow into the outskirt areas after the acceleration of suburbanisation because the relatively good environment, the looser regulations and large and relatively cheap properties were attractive for this group (Timár, 2001).

The selection between migration destinations is highly influenced by personal relationships and this contributes to an increase in segregation (Bajmócy \& Balogh, 2012a). Residents with similar social status move into the same street or section of road, thus they form closed groups at the outskirts. The first immigrants give the locality a good reputation, and later are followed by their colleagues and friends. Accordingly, some outskirts were almost exclusively dominated by teachers, doctors or policemen (Győr - Kertváros, Vámosszabadi - Zártkert, Győrzámoly - Solinka). In the cases where the houses are arranged in groups, the separation is even stronger. 
Table 3. The composition of local population of the sample areas (\%).

\begin{tabular}{|c|c|c|c|}
\hline \multicolumn{2}{|c|}{ Migration characteristics of respondents $(n=598)$} & Other inner areas & Outskirts \\
\hline \multicolumn{2}{|l|}{ Local born } & 45.8 & 8.4 \\
\hline \multicolumn{2}{|l|}{ Newcomer } & 53.4 & 58.4 \\
\hline \multirow{3}{*}{ Among newcomers } & From the main city & 22.8 & 43.6 \\
\hline & From other parts of the agglomeration & 14.9 & 7.8 \\
\hline & From abroad & 7.8 & 4.0 \\
\hline \multicolumn{2}{|c|}{ Periodically living in the city and at Outskirt/other inner area } & 0.8 & 33.2 \\
\hline
\end{tabular}

Source: own elaboration based on field survey

\section{Newcomers and locals, deprived groups and high-class residents: conflicts and problems in the suburbanising other inner areas and outskirts}

Due to the high rate of immigration to these areas, some serious social conflicts have evolved. The answers indicate that both the spatial segregation and close cohabitation of the different social groups can be the source of conflicts. Most often, the contrasts in earnings, different lifestyles and the newcomers' weak connections with local communities were the roots of the problems. Because the outskirts are populated by a wide range of different social and demographic groups, the differences in the revenue are especially high (Figure 4.) in this area. For example, there we can find high-status intellectuals living next to an underclass family who destitute in a winterized hut, which was originally built for agricultural purposes (Csatári et. al., 2013; Varadi, 2015). they do not express their opinion, even if you directly ask them...". As an easier way, most of them keep a distance from the newcomers, and they start to hinder the "non-locals" and "Audi-drivers" life. For example, they disrupt the flow of traffic and deliberately schedule the noisy tasks in the garden for the dawn as a specific and pointless way to protect their interests.

The deprived groups of the outskirts are hard to approach, and their financial difficulties often remain unseen. Some of them were squeezed out of the city because of the high utility costs or dept problems or they are slightly impoverished pensioners who are "actually hide at the outskirt in shame", according to an interviewee from Zalaegerszeg. They do not ask assistance from the government or the society even

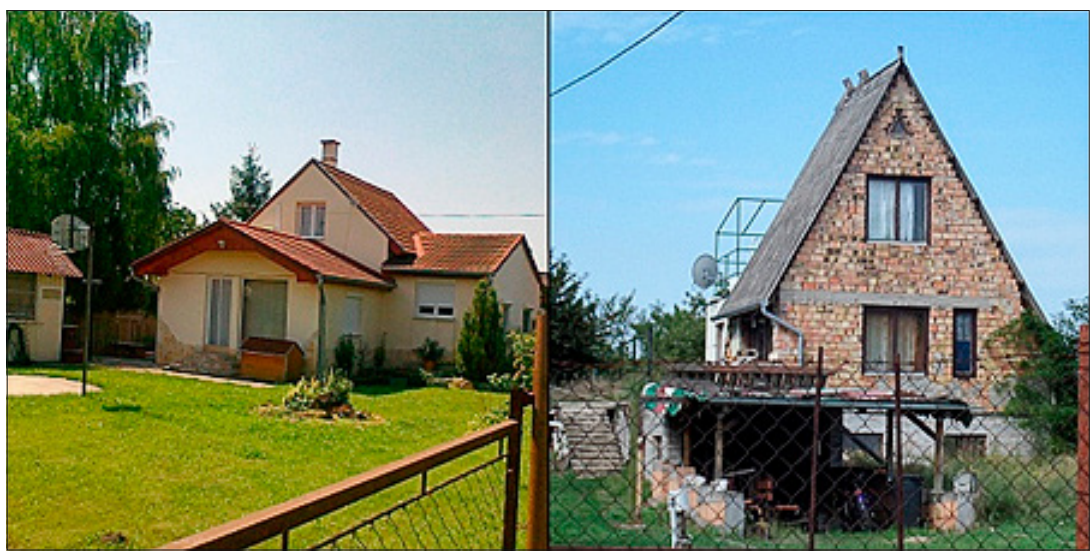

Figure 4. Suburban "palace" and poor home in the same outskirt garden zone Source: own photo

The newcomers' relations and social networks link them to the city. It is difficult to integrate into a new community, since they are not part of it and they have direct contact only with their direct neighbours. Some immigrants use the outskirt only as a commuter settlement and they are indifferent toward the local community. Local-born people do not have any lobbying ability, and as one interviewee from Zalaegerszeg expressed: „They believe they do not have a say in, so when they desperately need it. For this reason, it is common for pensioners and marginal families to live in vacation homes which are generally unfit for longer housing (e. g. in ones without heating). The social welfare system and the community have little information about these marginal groups.

The results of the survey revealed some of the problems of the residents. $31.4 \%$ of the respondents considered the condition of roads a pressing issue, because 
many streets are dangerous due to the too narrow roadways and the nearly total lack of sidewalks. Roadways without concrete base and eroded shoulder are unable to satisfy the demands of the current traffic. In many manors and tanya areas there are no permanent streets, only pieces of land with trails on them. Especially families and single moms with children suffer from the transport constraints (Helling, 2002), thus living in a poorly accessible area have greater impact on the lives of women (Hirt, 2008). Some of these wives described it as a "home imprisonment” for the winter half of the year. Long commuting also takes time from tending the gardens (Soltész, 1990). Services, institutions and workplaces are only available in the inner core, thus city public transport is essential for the less affluent and older age groups. Therefore improving accessibility is decisive in shaping the future of these areas (Hardi, 2005).

Public transportation is not able to offset the negative effects of poor accessibility. It is difficult to reach bus stops in most of the outskirts, $32.6 \%$ of the respondents claimed they need to walk more than $3 \mathrm{~km}$, on roads which are in a poor state and impassable after heavy rain or winter season, to reach the nearest bus stop. The problems are further enhanced as some local residents are responding to the increasing traffic with the arbitrary closure of roads.

Disadvantages in infrastructure are compensated by the strong community and cheaper living, whereas people moved there accept certain difficulties in exchange for opportunities. Despite the hardships, $81.5 \%$ of the respondents like to live here, mostly because of the quiet way of life $(50.0 \%)$ and good accessibility (15.4\%). This fact is significant because most of the outskirts have degraded infrastructure.

Garden zones and wineyards are the most attractive outskirt types for suburban population, their cheapness $(28.6 \%)$, the environmental conditions (29.6\%) and the possibility of horticulture (37.1\%) are the main appeals. However, environmental advantages do not necessarily relate to the quality of living place, because overhead lines may pass through some outskirts, ruins or industrial areas may lie next to residential properties. Usually, the relief, a nearby forest or simply an open green space promise relatively better quality of life than a block of flats. Most of the streets are characterized by detached houses and weekend homes. Along the narrow, unpaved roads, dead-end streets and at the perimeters of habited areas a higher frequency of weedy, unused gardens and properties in poor condition can be observed (Csurgó, 2013).

Regardless of their location, the majority of manors have inferior building stock, nearly two-thirds of the buildings are in poor condition or almost ruined. The jointly owned row houses (originally built as servants' house before 1945) are outwardly uncared, because no one wants to spend on them, on the contrary the inside of flats in these buildings are often in good condition, since they feel it as their own.

Instead of residential functions, owners often want to strengthen the economic function of the manor, so they neglect the maintenance of buildings, keep the roads in poor condition and make living there more difficult in various ways in order to accelerate the depopulation process. A respondent even reported that she/he cannot receive her/his guests without the permission of the landowner in the manor. In few outskirts the noise of the newly built plant make everyday life impossible.

Despite any difficulties, the strong community and the low utility costs are powerful attractive factor, thus only $23 \%$ of the respondents wanted to move. Inhabitants of the segregated manors do not feel bad about their residential situation, in fact a significant number of them like to live here. They are socialized into this status, adapted to the circumstances, and their way of life is organised around their strong communities, which make them easier to overcome the problems. Györságpuszta is a vivid example, where an agro-industrial corporation has ploughed the gardens and ditches around the manor, but the marginalized residents living below poverty line started to dig a new ditch. The common goal reunified the community and helped them overcome apathy. After finishing the new ditch, they did not cease community work; they started to renovate their flats little by little.

Through the example of Táplánypuszta, we can also show the negative example of phenomenon we described above. This manor lies near to Győr, next to a highway, but without public utilities. After 1989 marginalised groups moved there, and they could not maintain the buildings, thus the outskirt started to decline. The local government was also unable to handle the problem, because all properties are privately owned in this manor. An abandoned and partly demolished former pig farm is deteriorating next to the habited houses. This ruin is a major source of threat, since a part of the population complements their earnings by excavating building materials. The properties that lie further from the highway are decayed, the backyards are full of junk and waste, and one of the row houses were burned out due to illegal electricity connections.

In spite of previously described situation, the local community is relatively strong there. Because of the poor accessibility of the manor and their limited financial possibilities, the residents can only count on each other. A high number of residents suffer from alcohol problems and most of them are temporarily or 
long-term unemployed. The population of the manor developed into a secluded and defensive local community based on reciprocity and the common feeling of deprivation. Therefore, people living there cut off almost every relationship with the residents of the nearby developing village, to which settlement the manor administratively belongs to.

In areas like these, the formation of self-helping communities based on reciprocity can be observed. These voluntarily segregated areas are common, Csá- ford in Zalaegerszeg, Bőny - Páskum, Győr - Fazekasvermek, Pósdomb, Győrságpuszta and Ikrény - Dózsa Major in the agglomeration of Györ, Sándorfalva - Kövágódülő and Tiszasziget - Térvárpuszta in the agglomeration of Szeged are typical examples. The differentiation of tanyas is going in the same way, marginalized groups and low-income single pensioners spatially concentrated in the most isolated buildings (Bordány - Meződűlő, Domaszék - Bojárhalom, partly Hódmezővásárhely - Kopáncs, Rárós).

\section{The transforming spatial structure of the rural-urban fringes of Hungary}

As a result of social processes, a more mosaic pattern of settlement morphology is under formation (Figure 5.). The modern houses of the new residents, and the most deteriorated houses populated by aged local-born ones are spatially concentrated, too. It is typical practice to construct new greenfield neighbourhoods near to poorest parts of the area due to low land prices. The significant and clearly visible difference among properties in a short distance makes the reshape of the settlement pattern even more striking and disturbing. Traditional streets have been undergone a relative depreciation since the expanding building stock of new streets has become the new baseline of comparison (Tóth, 2000).

The increase in the population of the outskirts leads only to the renewal of a small percent of the houses, because most newcomers want to build a new home. According to our field survey $15.1 \%$ of the buildings are new or recently renovated, and $8.2 \%$ of them are ruined or deserted. In this regard, the distinctive types of outskirts significantly differ from each other. For example, $60 \%$ of property stock of manors are ruined or in bad condition.

The illegal construction and expansion of buildings were found in each sample area. The newly built buildings are often too big and/or do not fit into the landscape, which reduces the environmental beauty of the locality (Váradi, 1999). The construction of estates with a floor area of around 100 sqm (without permission) on small plots renders the land-use planning and road-widening almost impossible. Despite the aforementioned issues, the local governments rarely make steps against this illegal sprawl in order to acquire the expected tax revenue and due to the already chaotic townscape.

In the other inner areas, the growth of housing stock is usually realized by increasing building density, filling out empty plots, carving out smaller empty plots from a larger property or opening new streets within low-density blocks rather than by greenfield investments. The relatively few new residential areas and gated communities are constructed along the main roads leading to the city centre from the other inner areas. This represents significant increase in the size of the residential areas for some areas. Investors are trying to achieve higher profits thus the typical sizes of plots developed after 2000 are extremely small; furthermore the number of duplexes and multi-unit houses are high.

The increasing housing density sharpens the already existing conflicts originated from settlement

Table 4. The composition of proprieties and plots by usage and condition at the sample areas.

\begin{tabular}{|c|c|c|c|c|}
\hline \multicolumn{2}{|c|}{$\begin{array}{l}\text { Real estate distribution, by } \\
\text { land use and condition }(\%) \\
(n=9290)\end{array}$} & $\begin{array}{c}\text { All } \\
\text { outskirts }\end{array}$ & $\begin{array}{c}\text { Outskirts with good accessibility } \\
\text { and landscape (Wine hills, Garden } \\
\text { zones and Periurban streets) }\end{array}$ & $\begin{array}{l}\text { Outskirts with unfavourable } \\
\text { accessibility (Manors, } \\
\text { Tanyas, and other types) }\end{array}$ \\
\hline \multirow{2}{*}{ Gardens } & Unused & 10.9 & 4.9 & 11.4 \\
\hline & Hobby garden & 40.9 & 35.9 & 41.3 \\
\hline \multirow{5}{*}{$\begin{array}{l}\text { Plots with } \\
\text { building }\end{array}$} & New or renovated & 7.9 & 13.8 & 7.1 \\
\hline & Average & 31.8 & 35.5 & 31.0 \\
\hline & Poor condition & 3.0 & 5.8 & 4.1 \\
\hline & Uninhabitable & 2.2 & 1.3 & 2.1 \\
\hline & Ruined & 1.2 & 0.1 & 5.0 \\
\hline \multicolumn{2}{|c|}{ Plant. factory or commercial unit } & 2.4 & 0.4 & 27.4 \\
\hline
\end{tabular}

Source: own elaboration based on field survey 


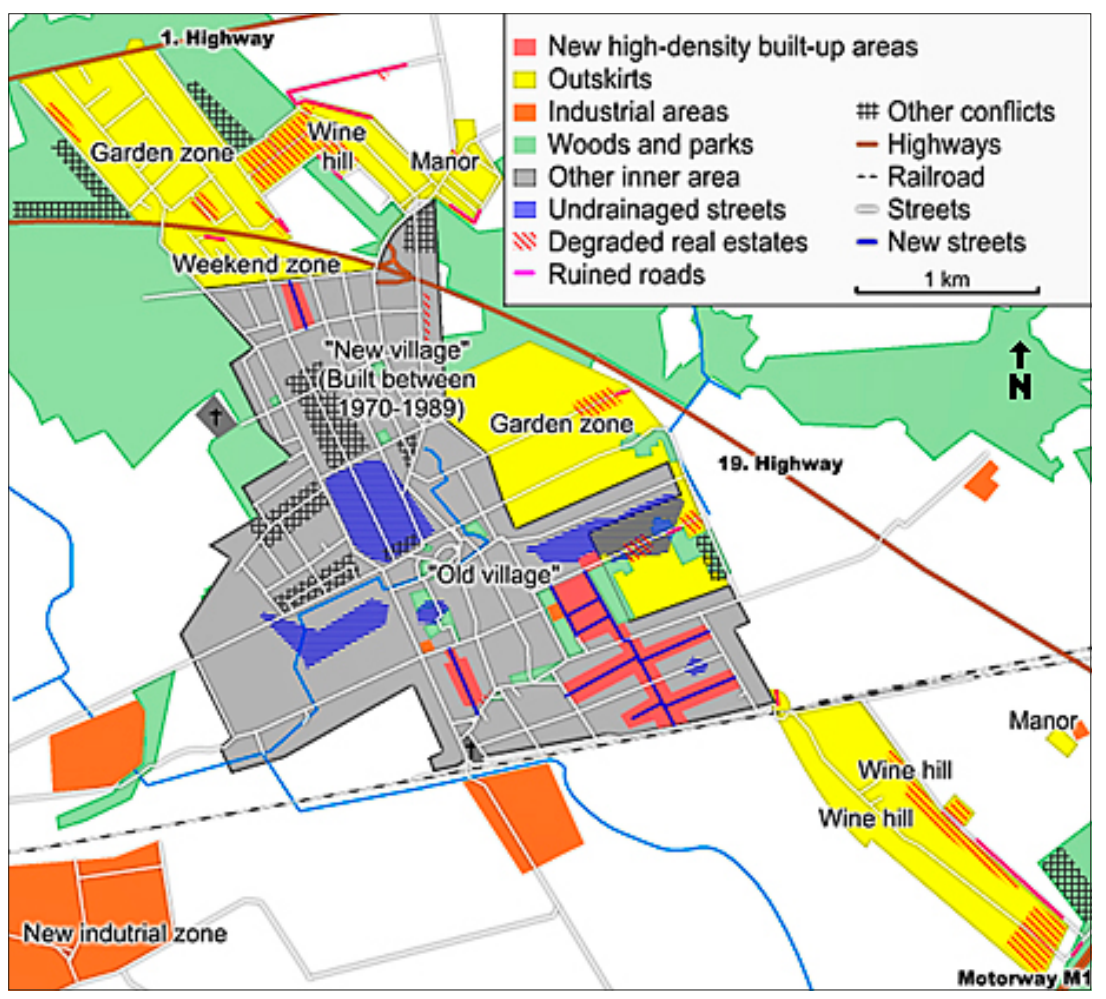

Figure 5. Spatial transformation and conflicts in an example other inner area, Győrszentiván Source: Edited by the authors

geographical characteristics. An excellent example for this is the issue of inland excess water, because many outskirts and other inner areas have fields without natural drainage outlet. In the seventies, a drainage system has been built, but the lack of maintenance and the expansion of built-up areas reduced the efficiency of the system. A lot of newcomers, who were less familiar with the local conditions, filled the ditches in the front yard, further obstructing drainage.

As a result, a highly complex spatial structure was formed in the peripheral areas of cities, particularly where the other inner areas and outskirts are relatively close to each other (Figure 6). In these areas, the mixing of different land use forms, social groups

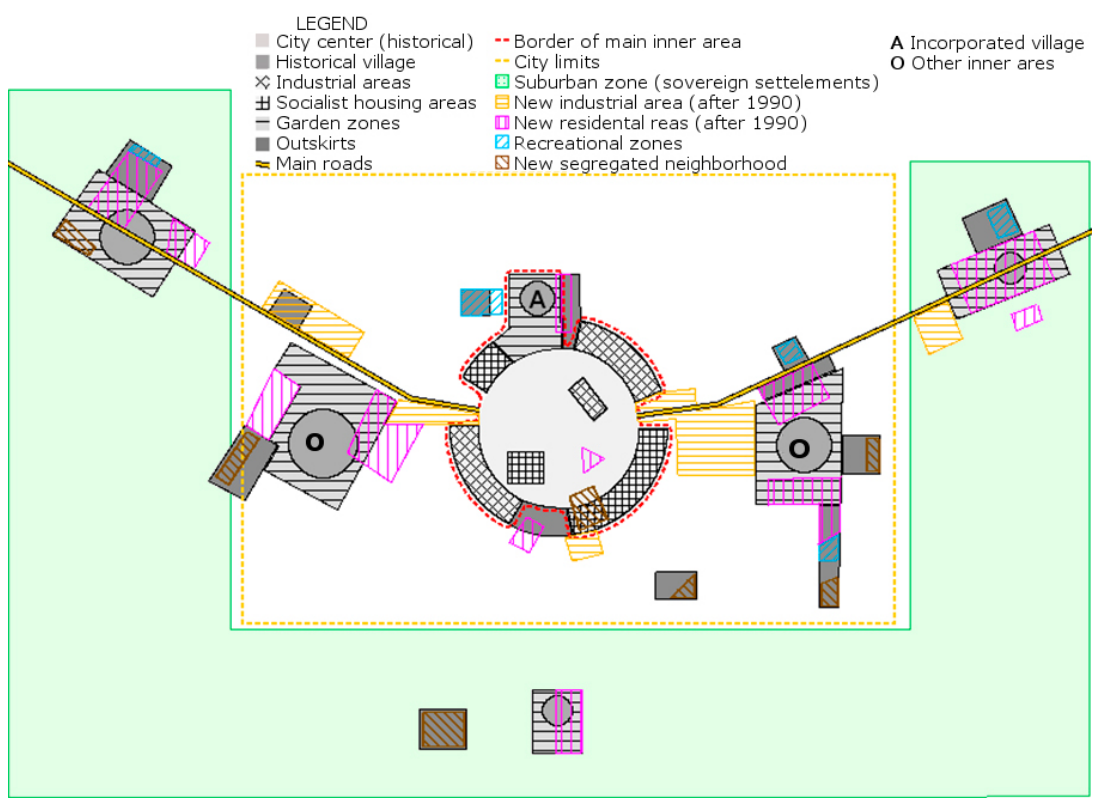

Figure 6 . The spatial structure of suburbanisation in case of a city with outskirts and other inner areas Source: Edited by authors 
and lifestyles are the main determinants of the chaotic land use patterns. As a consequence of the emerging conflicts and controversies, the local population declines and the newcomers begin to reshape the area according to their own perception. The existing development methods cannot handle the fragmented spatial structure. The fragmented spatial structure is typical in post-socialist cities (Ott, 2001).

In some areas, marginal and wealthy groups are concentrated in close proximity to each other and segrega- tion is not apparent in settlement level. Outskirts are attractive for both groups, but their land use profiles are different, thus there is a significant separation between groups of the population with distinct financial opportunities at micro level. Because of the myriad of emerging conflicts, neither groups are able to fully enjoy the benefits of the locality; moreover, the cohesive strength of the local community is eroded in the long term. In addition, the overused or missing elements of infrastructure further reduce the quality of life in these areas.

\section{Conclusion}

Because of the special settlement system in Hungary a municipality can be divided into three parts, the central inner area (core city), other inner areas (incorporated settlements) and outskirts. In this paper we examined the structural and social features of the rural urban fringe zone of four Hungarian cities. The analysed areas are characterized by the intense inflow into the outskirts and other inner areas. This process is both driven by marginal and high status groups, and the two groups often move to the same neighbourhoods. This process generates numerous positive effects, the infrastructure and building stock is partially renewing and the population is growing, and what is more important to the local governments, the tax revenues are also growing.

Dynamic changes have generated numerous conflicts, the infrastructure is overused, illegal land use changes and construction has become common. Local governments are often turning a blind eye to the numerous irregularities for the hoped tax revenues. Segregation in the outskirts decreases and grows simultaneously. Within the outskirts separation is greatly reduced because the newcomers are moving to plots currently available for sale. This leads to an almost random pattern, which is slightly modified by the state of infrastructure. However, in the attractive outskirts and other inner areas rural gentrification process starts, then newcomers may displace the old residents.

In contrast to the previous researches, neither the distance from the centre nor physical conditions are decisive factors. Accessibility - especially the availability of public transport - has the greatest impact on the development of those areas; hence a patchy and mosaic-like spatial structure is formed instead of a coherent ring of suburbia in the rural-urban fringe of Hungarian towns and cities. At a micro level renewing and rapidly declining zones are randomly located in the areas and there may be some hot spots of changes developing in the opposite direction within a street. Therefore suburbanisation at outskirts and other inner areas is slightly different from the forms of the sovereign villages and towns in agglomerations which have been examined in detail.

Local governments cannot handle these phenomena, because they do not have the necessary funding, and on the other hand, they don't have enough information even to survey the problem due to the distrustful, hardly approachable local residents and the lack of statistical databases. Therefore, settlement geography has a prominent role in laying the foundations of practical interventions aimed to resolve the numerous existing conflicts of the outskirts and other inner areas of the suburbs.

\section{References}

Antrop, M. (2004). Landscape change and the urbanization process in Europe. Landscape and Urban Planning, 67(1-4), 9-26. doi:10.1016/so1692046(03)00026-4

Bajmócy, P. (2003). Sikeresek, de falvak?, Nagyvárosaink néhány egyéb belterületének fejlőbése 1980tól napjainkig. In T. Kovács (Ed.), A vidéki Magyarország az EU-csatlakozás elött. VI. Falukonferencia. Pécs: MTA RKK - MRTT. Pécs, pp. 160-165. (in Hungarian with English summary).
Bajmócy, P. (2014). A szuburbanizáció két évtizede Magyarországon. In T. Kóródi, M.J. Sansumné, S.B. Siskáné, \& E. Dobos (Eds.), VII. Magyar Földrajzi Konferencia Kiadványa. Miskolc: Miskolci Egyetem Földrajz - Geoinformatika Intézet. pp. 24-34. (in Hungarian with English summary).

Bajmócy, P., \& Balogh, A. (2012). Egykori majorok tipizálása Vas megyei példákon. Földrajzi Közlemények, 2, pp. 165-181. (in Hungarian with English summary). 
Bajmócy, P., \& Makra, Z. (2016). Központi-, egyéb belterületek és külterületek népesedési trendjei $\mathrm{Ma}$ gyarországon 1960-2011 között. Településföldrajzi Tanulmányok, 2, pp. 3-21. (in Hungarian with English summary).

Balogh, A. (2012). A külterületek településföldrajzi vonatkozásai. Nyugat-Magyarországi Egyetem Savaria Egyetemi központ Tudományos közleményei (Természettudományok 14). Szombathely: NYME Kiadó. 127-138. (in Hungarian with English summary).

Balogh, A. (2012). A Nyugat-dunántúli régió külterületi településrészeinek földrajzi sajátosságai. In V. Pál (Ed.), A társadalomföldrajz lokális és globális kérdései: Tiszteletkötet Dr. Mészáros Rezső professzor 7o. születésnapja alkalmából. Szeged: SZTE TTIK Gazdaság- és Társadalomföldrajz Tanszék. pp. 134-145. (in Hungarian with English summary).

Balogh, A., \& Csapó, T. (2013). Manors and scattered farms. special settlement forms of outskirt areas in Hungary. Revijja Za Geografijo / Journal For Geography, 2, pp. 81-94.

Becsei, J. (2010). Az alföldi tanyarendszer településmorfológiai sajátosságai. Tér-Tálentum-Tanitványok, 1, pp. 57-72. (in Hungarian with English summary).

Becsei, J. (2015). Az alföldi tanyarendszer. In S. Kókai \& L. Boros (Eds.), Tiszteletkötet Dr. Gál András geográfus 6o. születésnapja alkalmából. Nyíregyháza-Szerencs: NyF TFI Bocskai István Katolikus Gimnázium. pp. 83-104. (in Hungarian with English summary).

Beluszky, P. (1982). Egy alig ismert településedsezeti elem, a kertség. Földrajzi Értesitő, 2-3, pp. 325-328. (in Hungarian).

Bourne, L.S. (1996). Reinventing the suburbs: Old myths and new realities. Progress in Planning, 46(3), 163-184. doi:10.1016/0305-9006(96)88868-4

Brade, I., Smigiel, C., \& Kovács, Z. (2009). Suburban residential development in post-socialist urban regions. the case of Moscow, Sofia, and Budapest.. In H. Kilper (Ed.), New Disparities in Spatial Development in Europe. (pp. 79-104). Berlin, Heidelberg: Springer Nature. doi:10.1007/978-3-642-03402-2_7

Brown, D.L., \& Schafft, K.A. (2002). Population deconcentration in Hungary during the post-socialist transformation. Journal of Rural Studies, 18(3), 233244. doi:10.1016/s0743-0167(01)ooo46-8

Bryant, C.R. (1995). The role of local actors in transforming the urban fringe. Journal of Rural Studies, 11(3), 255-267. doi:10.1016/0743-0167(95)ooo20-n

Clouth, H.D. (1976). Rural geography. an introductory survey. Oxford: Pergamon.

Csanádi, G., \& Csizmady, A. (2002). Szuburbanizáció és társadalom. Tér és társadalom, 3, pp. 83-107.
Csatári, B., \& Farkas, J. (2012). A város-vidék peremzóna sajátos geográfiai jellemzői és konfliktusai Kecskemét példáján. In A. Farsang, L. Mucsi, \& B.I. Keveiné (Eds.), Táj- érték, lépték, változás. Szeged: GeoLitera. pp. 197-210. (in Hungarian with English summary).

Csatári, B., Farkas, J.Z., \& Lennert, J. (2013). Land use changes in the rural-urban fringe of Kecskemét after the economic transition. Journal of Settlements and Spatial Planning, 2, pp. 153-159.

Dövényi, Z., \& Kovács, Z. (1999). A szuburbanizáció térbeni-társadalmi jellemzői Budapest környékén. Földrajzi Értesitö, 1-2, pp. 33-57. (in Hungarian with English summary).

Dövényi, Z. (2009). A belső vándormozgalom Magyarországon. Folyamatok és struktúrák. Statisztikai Szemle, 7-8, pp. 748-762. (in Hungarian with English summary).

Égető, M. (2003). A filoxéravésztől a második világháborúig. Rubicon, 1-2, pp. 84-87. (in Hungarian).

Gant, R.L., Robinson, G.M., \& Fazal, S. (2011). Landuse change in the 'edgelands': Policies and pressures in London's rural-urban fringe. Land Use Policy, 28(1), 266-279. doi:10.1016/j.landusepol.2010.06.007

Hardi, T. (2002). Szuburbanizációs jelenségek Győr környékén. Tér és Társadalom, 3, pp. 57-83. (in Hungarian with English summary).

Hardi, T., \& Nárai, M. (2005). Szuburbanizáció és közlekedés a győri agglomerációban. Tér és Társadalom, 1, pp. 81-101. (in Hungarian with English summary).

Hardi, T. (2012). Győr, Miskolc és Pécs agglomerációja a vidéki szuburbanizációban. In P.E. Somlyodyné (Ed.), Az agglomerációk intézményesitésének sajátos kérdései. Pécs: Publikon. pp. 15-42. (in Hungarian).

Helling, A. (2002). Transportation, Land Use and the Impacts on Srawl on Poor Children and Families. In G.D. Squires (Ed.), Urban Sprawl. Causes, Consequences, and Policy Responses. Washington DC: Urban Institute. pp. 119-139.

Hirt, S.A. (2008). Stuck in the suburbs? Gendered perspectives on living at the edge of the post-communist city. Cities, 25(6), 340-354. doi:10.1016/j.cities.2008.09.002

Kok, H., \& Kovács, Z. (1999). The process of suburbanization in the agglomeration of Budapest. Netherlands Journal of Housing and the Built Environment, 14(2), 119-141. doi:10.1007/bfo2496818

Kok, H. (1999). Migration from the city to the countryside in Hungary and Poland. GeoJournal, 49(1), 53-62. doi:10.1023/a:1007092228633

Kovács, A.D. (2010). Kecskemét-Méntelek - a sajátos helyzetű, tanyás városrész - településkörnyezeti jellemzői és társadalmának jövőbeni elképzelései. In V. Szabó \& I. Fazekas (Eds.), II. Települési Környezeti Konferencia. Debrecen: Debreceni Egyetem Tá- 
jvédelmi és Környezetföldrajzi Tanszék. pp. 49-54. (in Hungarian with English summary).

Kubeš, J. (2013). European post-socialist cities and their near hinterland in intra-urban geography literature. Bulletin of Geography. Socio-economic Series, 19(19), 19-43. doi:10.2478/bog-2013-0002

Mcmanus, R., \& Ethington, P.J. (2007). Suburbs in transition: new approaches to suburban history. Urban History, 34(02), 317-337. doi:10.1017/ so96392680700466x

Nuissl, H., \& Rink, D. (2005). The 'production' of urban sprawl in eastern Germany as a phenomenon of post-socialist transformation. Cities, 22(2), 123134. doi:10.1016/j.cities.2005.01.002

Ónodi, G., Cros, K.Z., Gubicua, C., Horváth, J., \& Molnár, M. (2002). A kertségek és kertművelés szerepe és jövője I. Településrendezési, szabályozási javaslatok. Falu-Város-Régió. Falu-Város-Régió, 2, pp. 3-8. (in Hungarian).

Ott, T. (2001). From Concentration to De-concentration - Migration Patterns in the Post-socialist City. Cities, 18(6), 403-412. doi:10.1016/so2642751(01)00032-4

Ouředníček, M. (2007). Differential suburban development in the prague urban region. Geografiska Annaler: Series B, Human Geography, 89(2), 111-126. doi:10.1111/j.1468-0467.2007.00243.x

Phillips, M. (2009). Counterurbanisation and rural gentrification: an exploration of the terms. Population, Space and Place, 6, 539-558. doi:10.1002/psp.570

Pacione, M. (2013). Private profit, public interest and land use planning-A conflict interpretation of residential development pressure in Glasgow's ruralurban fringe. Land Use Policy, 32, 61-77. doi:10.1016/j. landusepol.2012.09.013

Pócsi, G. (2009). Dinamikus átalakulások Budaihegyen, Kecskemét város-vidék peremzónájában. In T. Csapó \& (. Kocsis (Eds.), A közép-és nagyvárosok településföldrajza. Szombathely: Savaria University Press. pp. 322-334. (in Hungarian with English summary).

Pócsi, G. (2011). Land Use Change of the 'Small Hobby Gardens' in the Peri-Urban Area of Szeged, Hungary. Forum geografic, 10(2), 312-321. doi:10.5775/ fg.2067-4635.2011.018.d

Pryor, R.J. (1968). Defining the Rural-Urban Fringe. Social Forces, 47(2), 202-215. doi:10.2307/2575150

Roose, A., Kull, A., Gauk, M., \& Tali, T. (2013). Land use policy shocks in the post-communist urban fringe: A case study of Estonia. Land Use Policy, 30(1), 76-83. doi:10.1016/j.landusepol.2012.02.008

Sharp, J.S., \& Clark, J.K. (2008). Between the Country and the Concrete: Rediscovering the Rural-Urban Fringe. City \& Community, 7(1), 61-79. doi:10.1111/ j.1540-6040.2007.00241.x
Schafft, K. (2000). A network approach to understanding post-socialist rural inequality in the 1990's. Eastern European Countryside, 6, pp. 25-40.

Schuchmann, J. (2010). Szuburbanizáció vagy Reurbanizáció jellemzi ma a Budapesti agglommerációt?, Válaszok az eltérő fejlettségű szuburbán lakosság lakóhelyi elégedettsége és költözési szándékainak elemzése alapján. In T. Csapó \& (. Kocsis (Eds.), A településföldrajz aktuális kérdései. Szombahely: Savaria Press. 131-142. (in Hungarian with English summary).

Soltész, J. (1990). Borsod-Abaúj-Zemplén megye zártkertjeinek helyzete, különös tekintettel a Tokaj-Hegyaljai történelmi borvidékre. A Falu, 4, pp. 33-40.

Stockdale, A. (2010). The diverse geographies of rural gentrification in Scotland. Journal of Rural Studies, 26(1), 31-40. doi:10.1016/j.jrurstud.2009.04.001

Sýkora, L., \& Bouzarovski, S. (2012). Multiple Transformations. Conceptualising the Post-communist Urban Transition. Urban Studies, 49(1), 43-60. doi:10.1177/0042098010397402

Szelényi, I. (1996). „Cities under Socialism - and After. „In Cities After Socialism. Urban and Regional Change and Conflict. In G. Andrusz, M. Harloe, \& I. Szelényi (Eds.), Post-Socialist Societies. Oxford: Blackwell. pp. 286-317.

Szirmai, V. (2011). Urban sprawl in Europe. An Introduction. In V. Szirmai (Ed.), Urban Sprawl in Europe. Similarities or Differences?. Budapest: Aula Kiadó. pp. 15-44.

Tammaru, T. (2001). Suburban Growth and Suburbanisation under Central Planning: The Case of Soviet Estonia. Urban Studies, 38(8), 1341-1357. doi:10.1080/00420980123612

Timár, J. (1993). A városok körüli rurális peremzóna átalakulásának néhány sajátossága az alföldön. In. Kovács, T. (eds). Kiút a Válságból. II. falukonferencia. MTA RKK, Pécs, in Hungarian with English summary). In T. Kovács (Ed.), Kiút a Válságból. II. falukonferencia. Pécs: MTA RKK. pp. 303-308.

Timár, J. (1990). Kérdőjelek és hiányjelek a tanyakutatásban. Tér és Társadalom, 2, pp. 49-62. (in Hungarian with English summary).

Timár, J. (1999). Elméleti kérdések a szuburbanizációról. Földrajzi Értesitö, 1-2, pp. 7-31. (in Hungarian with English summary).

Timár, J., \& Baukó, T. (1999). A „város-vidék peremzóna", néhány sajátossága és szerepe az alföldi városok átalakulásában. Alföldi tanulmányok, 17, pp. 94-111. (in Hungarian with English summary).

Timár, J. (2001). A háztartási „túlélési stratégiák” területi szempontú kutatásának néhány elméleti kérdése és empirikus eredménye az átmenet időszakában Magyarországon. In Z.I. Ekéné (Ed.), 10 éves 
a Debreceni Egyetem Társadalomföldrajzi és Területfejlesztési Tanszéke. Debrecen: DE Társadalomföldrajzi és Területfejlesztési Tanszé. pp. 209-218. (in Hungarian with English summary).

Timár, J., \& Váradi, M.M. (2001). The uneven development of suburbanisation during transition in Hungary. European Urban and Regional Studies, 4, pp. 349-360..

Timár, J. (2010). Van-e posztszocialista urbanizáció?, néhány gondolat a magyarországi szuburbanizációról és dzsentrifikációról. In. Barta, Gy. et. al. (eds.). A területi kutatások csomópontjai. MTA RKK, Pécs, in Hungarian with English summary). In (. Barta \& et. al. (Eds.), A területi kutatások csomópontjai. Pécs: MTA RKK.

Tóth, Z. (2000). Településkörnyezet II. Az épített környezet. In G. Enyedi (Ed.), Magyarország településkörnyezete. Budapest: MTA. pp. 151-186. (in Hungarian).

Váradi, M.M. (2013). Megélhetés és támogató kapcsolatok - az aprófalusi szegénység arcai. Esettanulmány 2008-ból. In K. Kovács \& M.M. Váradi (Eds.), Hátrányban vidéken. Budapest: Argumentum Kiadó. pp. 106-131. (in Hungarian with English summary).

Váradi, M.M. (2015). A túlélés és a társadalmi betagolódás között. szegénység, kirekesztettség és kapcsolatrendszerek. In T. Virág (Ed.), Törésvonalak. Szegénység és etnicitás vidéki terekben.. Budapest: Argumentum Kiadó. 45-68. (in Hungarian with English summary).

Váradi, M.M. (1999). Hová megyünk lakni?, Szuburbanizációs minták és konfliktusok a budapesti agglomeráció budai oldalán. Esettanulmány. In (. Barta \& P. Beluszky (Eds.), Társadalmi-gazdasági átalakulás a budapesti agglomerációban. Budapest: Regionális Kutatási Alapítvány. 115-129.

Weaver, D.B., \& Lawton, L.J. (2001). Resident Perceptions in the Urban-Rural Fringe. Annals of Tourism Research, 2, pp. 439-458.

Yue, W., Liu, Y., \& Fan, P. (2013). Measuring urban sprawl and its drivers in large Chinese cities. The case of Hangzhou. Land Use Policy, 31, 358-370. 